\title{
Effect of selenium and vitamin E supplementation as a nutritional treatment for some physiological and productive traits of Holstein dairy cows under Egyptian summer conditions
}

\author{
Hisham H. Khalifa, Safwat M.A., El Sysy M.A.I and Al-Metwaly, M.A. \\ Dept. of Animal Production, Faculty of Agriculture, Al-AZhar University.
}

\begin{abstract}
The present study was carried out at Sanad Company for Animal Production, Damietta governorate, Egypt, during the period from June to September 2013 (summer). Twenty healthy Holstein dairy cows, free from diseases, of similar age (3 years old) and average body weight $(500 \pm 25 \mathrm{~kg})$ and $(80 \pm 10$ days in milk) were used in the present study. All animals were at the second season of lactation in summer season. Animals were randomly assigned into four experimental groups (each of 5 animals): G1 was intramuscular injected at biweekly intervals with $10 \mathrm{ml}$ saline solution and served as a control group, G2 was intramuscular injected every two weeks with $10 \mathrm{ml}$ viteselen, G3 was intramuscular injected every two weeks with $20 \mathrm{ml}$ viteselen and G4 was supplemented in their daily ration with 3mg, organic Selenium (O-Se)/ kg DMI. Productive (milk: production, fat, protein, lactose, total solids, solids non-fat and somatic cell count), blood chemical (plasma: Glutathione peroxides, proteins, urea, ALT, AST, glucose, cholesterol and triglycerides) and physiological parameters (rectal temperature and respiration rate) were measured at the start and the end of 60 days experimental period.

Results indicated that Se treatment either in inorganic or in organic forms with or without vit. E. did not affect significantly all productive, blood chemistry and physiological parameters expect somatic cell count and Glutathione peroxides. It can be concluded that, the main effect of Se treatment is the reduction of somatic cell count due to its effect on immunity; meanwhile, Se had no role in alleviation of heat stress under summer conditions at Northern region (Delta) of Egypt.
\end{abstract}

Key words: Selenium, Vitamin E, Dairy cow, Summer.

\section{INTRODUCTION}

Minerals and vitamins play an important role in the growth and reproductive performance of farm animals. Selenium (Se) is an important trace mineral, acting in synergism with vitamin $\mathrm{E}$ which prevents the oxidation of membrane polyunsaturated fatty acids and DNA by oxygen radicals produced throughout aerobic metabolism (Koyuncu and Yerlikaya 2007). Se has a biological function related to vitamin $E$ in that it is an important component of glutathion peroxidase, an enzyme involved in detoxification of hydrogen peroxide and lipid hydroperoxides. Furthermore, Se is a component of selenoproteins and is involved in immune function in farm animals (Meschy, 2000; Ružić-Muslić et al., 2014). Se deficiency plays a role in several economically important livestock diseases; problems that include decreased fertility, abortion, retained placenta and neonatal weakness (McDowell et al., 1996). According to Moeini et al. (2011) a high level of Se and vitamin $\mathrm{E}$ in heifers in 
late pregnancy had positive effect on immune system. It has also been reported that, Se and vitamin $\mathrm{E}$ status in the parturient period and during early life is important for health and performance of cows and their offspring (Lacetera et al., 1996). Moreover, the mean milk yield and milk composition of cows receiving supplemental inorganic selenium (as sodium selenite) and organic selenium (as selenium yeast) were greater for cows receiving organic selenium (Silvestre et al., 2007).

Vitamin E, as a dietary essential fat-soluble vitamin, can improve animal performance when provided in amounts above minimal requirements. Due to the potent antioxidant properties of tocopherols, the impact of $\alpha$-tocopherol in the prevention of chronic diseases believed to be associated with oxidative stress has often been studied and beneficial effects have been demonstrated (Brigelius and Traber 1999). The biological effects of vitamin E are mostly seen in the prevention of resorption of fetuses, testicular degeneration, muscle dystrophy, anemia and encephalomalacia; the classical signs of vitamin E deficiency in animals. The influence of vitamin $\mathrm{E}$ on the immune system has also become an important issue (Politis et al., 1995 and 1996). Nockels, (1986) recommended that, vitamin E at 6 to 20 times the NRC-recommended concentrations would improve the immune response of farm animals.

Among the stressors, heat stress has been of major concern in reducing animal's productivity in tropical, sub-tropical and arid areas (Silanikove et al., 1997). Therefore, the objective of the present study was to evaluate the effects of supplementation with selenium in either organic or inorganic forms or vitamin E on some physiological and productive traits of Holstein dairy cows under Egyptian summer conditions.

\section{MATERIALS AND METHODS}

The present study was carried out at Sanad Company for Animal Production, Damietta governorate, Egypt, during the period from June to September 2013 (summer).

\section{Animal feeding and management:}

Twenty healthy Holstein dairy Cows with similar age (3 years old), average body weight $(500 \pm 25 \mathrm{~kg})$ and $(80 \pm 10$ days in milk) were used in the present study. All animals were at the second season of lactation. They were randomly assigned into four experimental groups (each of 5 animals).

The first group of cows (G1) was intramuscular injected with saline solution $10 \mathrm{ml}$ at biweekly intervals and for 60 days and served as a control group (C).

The second group (G2) was intramuscular injected every two weeks for 60 days with $10 \mathrm{ml}$ viteselen (manufactured by ADWIA Co., S.A.E. $10^{\text {th }}$ of Ramadan City Egypt). Each $1 \mathrm{ml}$ of viteselen contains vitamin E, $150 \mathrm{ml}$ acetate and $1.67 \mathrm{mg}$ sodium selenite as inorganic vit $\mathrm{E}$ and selenium source.

The third group (G3) was intramuscular injected with $20 \mathrm{ml}$ viteselen every two weeks for 60 days.

The fourth group (G4): Animals were supplemented in their daily ration with $0.3 \mathrm{mg}$ organic Selenium (O-Se)/kg daily DMI. The daily organic Selenium supplement contained, $1 \mathrm{~g} \mathrm{Se} / \mathrm{kg}$, produced from Saccharomyces cerevisiae (CNCM I-3060, Sel-Plex ${ }$, Alltech 
Effect of selenium and vitamin E supplementation as a nutritional treatment for some physiological and productive traits of Holstein dairy cows under Egyptian summer conditions

Biotechnology, Beijing, China). The experimental period lasted for 60 days; 30 days as an adaptation period followed by 30 days for milk determination.

\section{Samples collection and experimental measurements:}

Experimental animals were raised in open yards, under an ambient temperature (24-34 ${ }^{\circ} \mathrm{C}$ ) and relative humidity (63-100\%). Animals were daily fed ad libitum a total mixed ration (Tables 1 \& 2), after each milking, according to recommendation of NRC (2001). Experimental animals were milked three times a day i.e. 0.6, 14.00 and $21 \mathrm{hrs} . / \mathrm{day}$, respectively. The total milk yield / cow was recorded weekly during lactation by milk meter apparatus.

Table (1). Daily feed intake /h/day (kg) of Holstein dairy cows in summer on fed basis.

\begin{tabular}{|c|c|c|}
\hline & Ingredients & Daily intake/h/d(kg) \\
\hline 1 & Magnabac & 0.482 \\
\hline 2 & Soya bean & 1.883 \\
\hline 3 & Cotton seed & 1.234 \\
\hline 4 & Corn grains & 6.025 \\
\hline 5 & Gluten feed & 2.840 \\
\hline 6 & Linseed meal & 2.625 \\
\hline 7 & Wheat bran & 0.550 \\
\hline 8 & Hay & 0.503 \\
\hline 9 & Alfalfa & 11.719 \\
\hline 10 & Corn silage & 12.597 \\
\hline \multicolumn{3}{|c|}{ Feed additives /h/d: } \\
\hline 1 & Sodium bicarbonate & 0.134 \\
\hline 2 & Sodium chloride & 0.134 \\
\hline 3 & Calcium carbonate & 0.188 \\
\hline 4 & High dairy vitamins. & 0.020 \\
\hline 5 & High dairy minrals. & 0.020 \\
\hline 6 & Potassium phosphate & 0.054 \\
\hline & Total feed intake /h/ day (kg) & 41.000 \\
\hline
\end{tabular}

Table (2): chemical composition of daily feed intake of Holstein dairy cows in summer (h/day)

\begin{tabular}{|c|c|}
\hline Ingredients & Intake/h/d \\
\hline Dry matter intake /h/d(kg) on (DM basis) & 22.547 \\
\hline Crude protein $(\mathrm{CP})$ & 4.176 \\
\hline Net energy for lactation $\left(\mathrm{NE}_{\mathrm{L}}\right) ;$ Mcal & 39.414 \\
\hline $\mathrm{TDNI}(\mathrm{kg})$ & 16.469 \\
\hline $\mathrm{NDFI} / \mathrm{h} / \mathrm{d}$ & 6.862 \\
\hline $\mathrm{ADFI} / \mathrm{h} / \mathrm{d}$ & 3.860 \\
\hline Non fiber carbohydrate intake $/ \mathrm{h} / \mathrm{d}(\mathrm{kg})$ & 7.901 \\
\hline $\mathrm{NE}_{\mathrm{L}}$ for lactation / CP & 9.438 \\
\hline Ca / P ratio & 2.000 \\
\hline
\end{tabular}


Hisham H. Khalifa et al.

\section{Measurements of productive traits and Physiological parameters: Productive traits:}

The total milk yield of different experimental cows groups was recorded at biweekly intervals per each lactating animal for 60 days, by a milky meter apparatus, while samples/ each milking i.e. morning, afternoon and evening were collected and a composite sample was kept fresh until later chemical analysis. Milk samples were chemically analyzed to estimate fat, protein, total solids (TS), solids not fat (SNF) and lactose content by Milko Scan instrument and Somatic cell count by Fossomatic 5000 (Combifoss, Denmark) in Milk Laboratory belongs to Animal Production Research Institute (APRI), Kafr El-Sheikh Governorate, Egypt.

\section{Physiological parameters \\ Blood and plasma parameters}

Heparinized blood samples were collected weekly from the jugular vein of cows in at mid-day (14.00.hrs). Plasma samples were collected by centrifugation of heparinized blood samples at 3000 r.p.m for 10 minutes. Blood plasma was kept frozen at $-20{ }^{\circ} \mathrm{C}$ until determination of Glutathione peroxidase (GSH-Px), alanine aminotransferase (ALT), aspartate aminotransferase (AST), total protein (TP), Plasma albumin, Plasma urea, Plasma glucose, total cholesterol (TC) and triglycerides (TG) using a commercial kit (Biodiagnostic, Egypt).

\section{Thermoregulatory parameters:}

Rectal temperature (RT, ${ }^{\circ} \mathrm{C}$ ) was daily measured at 14:00 using veterinary thermometer with an accuracy of $\left( \pm 0.1^{\circ} \mathrm{C}\right)$ inserted about $6-7 \mathrm{~cm}$ into the rectum for one minutes. Respiration rate (RR) (breaths / $\mathrm{min}$ ) was daily counted at 14:00 by observing flank movements for a period of one-minute using stopwatch.

\section{Meteorological parameters:}

The meteorological data were obtained from Central Laboratory of Agricultural Climate, including ambient temperature (Ta); percent of relative humidity $(\mathrm{RH})$, while temperature Humidity Index (THI) was calculated according to Amundson et al. (2006) and Abd El-Ghany et al. (2010), as following:

$$
\left.\mathrm{THI}=0.8 \times \mathrm{Ta}{ }^{\circ} \mathrm{C}+\left\{(\mathrm{RHi} \%) \times\left(\mathrm{Ta}{ }^{\circ} \mathrm{C}-14.4\right) / 100\right)\right\}+46.4 .
$$

Where; $\mathrm{Ta}{ }^{\circ} \mathrm{C}$ is the ambient temperature $\left({ }^{\circ} \mathrm{C}\right)$, and $\mathrm{RH}$ is the relative humidity ( $\left.\mathrm{RH} \%\right) / 100$.

\section{Statistical analysis:}

Analysis of variance was computed using the General linear Model procedure using SPSS program (SPSS, 1997). Variable means for treatments indicating significant differences in the ANOVA were compared and the differences were indicating using Duncan, multiple range tests (Duncan, 1955). 
Effect of selenium and vitamin E supplementation as a nutritional treatment for some physiological and productive traits of Holstein dairy cows under Egyptian summer conditions

\section{RESULTS AND DISSCUSION}

\section{Meteorological data}

The values of ambient temperature, percent of relative humidity (RH) and temperature Humidity Index (THI) for July and August, 2013 were shown in Table (3). The average ambient temperature during July and August, 2013 ranged from $27.47{ }^{\circ} \mathrm{C}$ to $28.13^{\circ} \mathrm{C}$. While, the respective average $\mathrm{RH}$ were $81.03 \%$ and $83.47 \%$.

The average values of THI were 78.96 and 80.37 for July and August, respectively. THI value of 68 is considered the upper limit of dairy cattle comfort zone (Johnson et al., 1989; Marai and Habeeb, 2010). Temperature humidity index value of 74 to 78 is considered hazardous and represents an alert condition for animals (Abd El-Ghany et al., 2010). The present data indicated that animals were under heat stress during day and within the thermoneutral zone during night according to Davis et al .(2003).

Table (3): Means of ambient temperature $\left({ }^{\circ} \mathrm{C}\right)$, relative humidity $(\%)$ and temperature humidity index (THI) during July and august 2013.

\begin{tabular}{|c|c|c|c|c|c|c|c|}
\hline \multirow{2}{*}{ Month } & \multicolumn{2}{|c|}{ Ambient Temperature $\left({ }^{\circ} \mathbf{C}\right)$} & \multicolumn{3}{c|}{ Relative Humidity (\%) } & THI average \\
\cline { 2 - 8 } & high & low & avg & high & low & avg & \\
\hline July & 29.83 & 24.73 & 27.47 & 93.03 & 62.83 & 81.03 & 78.96 \\
\hline August & 30.97 & 25.63 & 28.13 & 95.43 & 66.63 & 83.47 & 80.37 \\
\hline
\end{tabular}

\section{Milk production parameters}

\section{Milk production}

Table (4) indicated that there was no significant difference between the treatments groups, while all treatments were higher than the control group and the third group was the highest one, followed by the fourth group and then the second group. These results are in accordance with that of EL-Nenaey, (1993) who found that, milk yield was higher in treated groups than control. However, the differences were not significant. Lacetera et al. (1996), Pauselli et al.(2001), Harrison et al. (2005) reported that the replacement of mineral Se supplement in dairy cow diets by Sel-Plex selenium yeast resulted in productivity increase on average of $1.4 \mathrm{~kg} /$ cow daily. Wang et al. (2009) founded that supplementation of diet with selenium-yeast improved the milk yields. Milk yields were higher $(\mathrm{P} \leq 0.05)$ for $150,300 \mathrm{mg}$ selenium yeast per $\mathrm{kg}$ of diet dry matter (DM), than for $450 \mathrm{mg}$ selenium yeast per $\mathrm{kg}$ of diet dry matter (DM) and the control (Qureshi et al., 2010 ; Eulogio et al., 2012). An increase in milk yields was recorded when cows supplemented with SY or injected with veteselin as compared with control and this resulted from the improvement of feed digestion since DM intake did not differ (Wang et al., 2009). In addition, in dairy cows selenium deficiency results in a decrease in milk production and in the functioning of the immune system, resulting in an increase of vulnerability to illnesses, including the illnesses of the mammary gland (Krzyżewski et al., 2014). Selenium and vitamin E can prevent the occurrence of mastitis and subsequently improve milk compositions and quality. 
Hisham H. Khalifa et al.

\section{Milk fat:}

Milk fat did differ significantly between the groups, although the fourth group was the highest, followed by the third group then the control group and the second group (Table 3). The present result was in agreement with Harrison et al. (2005), Wang et al. (2009), Faye et al. (2014), but the little increment in fat percentage agreed with the results of Silvestre et al. (2007) who reported that both monthly fat and protein percent were greater for cows receiving Sel-Plex. Pechová et al. (2008) and Liu et al. (2008) founded that vitamin E and selenium supplementation increased the concentration and production of milk fat which were significantly higher $(\mathrm{p}<0.05)$ in HVE and HSeVE groups. Compared with the control diet, the milk fat percentage was increased 15.1 and $16.6 \%$ by the HVE and HSeVE diet, respectively. Since the main precursors of milk fat originate in the rumen, the increased milk fat content may have been influenced by rumen fermentation. The effect of Se supplementation in the form of yeast on the rumen fermentation was studied by Faixová et al. (2007) who found significantly higher activity of alkaline phosphatase and glutamate dehydrogenase in ruminal fluid in Se-supplemented group. They explained it by the supportive effect of Se on rumen microbial population, increasing their resistance and activity. Similarly Mihaliková et al. (2005) documented a protective effect of Se feed supplementation on the development of some rumen ciliate species in young sheep. This increase can be connected with the decrease in Serum cells count and with the cases of clinical mastitis that occurred in this treatment. According to Duncan et al. (1991) animals with low incidence of mastitis presented larger concentrations of milk fat, due to the lower enzymatic action of lipases of leukocytes origin, which increases in conditions of immune stress.

\section{Milk protein}

Table (4) showed that in the summer season the effect of treatments on milk protein was significantly where G3 was significantly higher than other treatments and control, also G2 and G4 were significantly higher than control.

The significant effect of treatment with Se or Se+Vit. E was in accordance with the result of Silvestre et al. (2007) who showed that, monthly fat percent was greater for cows receiving Sel-Plex. Eulogio et al. (2012) reported that performance responses to selenium and vitamin E supplementation increases $(\mathrm{p}<0.05)$ percentage of Crude Protein $(\mathrm{CP})$. Pirestani et al. (2014) found that selenium + vitamin E significantly enhanced milk protein compared to other treatments. Selenium and vitamin E can prevent the occurrence of mastitis and subsequently improve milk compositions and quality (Erskine et al., 1990; Erskine et al., 1989; Weiss, 2002).

\section{Milk lactose}

Table (4) revealed that in the summer season the effect of treatments on milk lactose was not significantly but all treatments trended to be higher than control. This result was in agreement with Pirestani et al. (2014) who found that selenium + vitamin E increased milk lactose compared to control and other treatment groups but no significant difference was found. Oliver and Calvinho (1995) showed that the major components of milk such as lactose, fat, and casein are decreased during inflammation, indicating that cellular synthesis has been altered. 
Effect of selenium and vitamin $\mathbf{E}$ supplementation as a nutritional treatment for some physiological and productive traits of Holstein dairy cows under Egyptian summer conditions

\section{Milk total solids (TS)}

Table (4) indicated that in summer, all treatments did not affect milk TS significantly although all treatment were higher than control. This was in accordance with that of Juniper et al. (2006), Heard et al. (2007), Paschoal (2007), Wang et al. (2009) and Eulogio et al. (2012) who found that the total solids (TS) was not affected by treatment. Oltramari et al., (2014) showed that the experimental diets had no effect on solids-not-fat percentage in the milk.

\section{Milk solids not fat (SNF)}

Table (4) revealed that treatments did not affect milk SNF significantly although all treatment were higher than control. This result was in accordance with the previous result given by Eulogio et al. (2012) who found that selenium and vitamin E supplementation increases $(\mathrm{p}<0.05)$ percentage solids not fat $(\mathrm{SNF})$. Pirestani et al. (2014) reported that selenium + vitamin E treatment group also increased milk SNF compared to control and other treatment groups but no significant difference was found. Oltramari et al. (2014) showed that the experimental diets had no effect on solids not-fat percentage in the milk $(\mathrm{P}=0.05)$. Similar results were obtained by Juniper et al. (2006), Heard et al. (2007), Paschoal (2007) and Wang et al. (2009).

\section{Somatic cells count}

Table (4) indicated that somatic cells count was higher in G1 (control) than all other groups and being significant with G4, where, the lowest value was recorded in G4. These results are in accordance with that of Morgante et al. (1999) who showed that selenium and vitamin $\mathrm{E}$ administration in selenium-deficient pregnant ewes 45 days before parturition lead to reduce somatic cell counts post-lambing and there were a positive association between selenium and/or vitamin $\mathrm{E}$ with reduced incidence of clinical mastitis and lower numbers of somatic cell counts in dairy cow.

After adding Se-yeast to the daily ration, cows somatic cells counts decreased significantly $(\mathrm{p}<0.01)$ with the increase of Se-yeast and feeding time. By the end of this experiment, somatic cells counts of the control group had no significant change while the treat groups decreased respectively by $22.76 \%, 24.57 \%$ and $31.59 \%(\mathrm{P}<0.01)$ compared with those before this experiment (Zong-yum et al., 2007). Sánchez et al. (2007) concluded that Se supplement is indispensable for the prevention of mastitis in goats. Eulogio et al. (2012) showed that decreased number of Somatic Cells Count was attributable to dietary Se and vitamin E supplementation. Pirestani et al. (2014) indicated that $\mathrm{Se}+\mathrm{Vit} \mathrm{E}+\mathrm{Cu}$ injection markedly reduced Somatic Cells Count as compared to other experimental treatments.

Balicka-Ramisz and Jastrzębski (2014) showed that cows fed a diet containing suboptimal concentrations of Se $(<0.05 \mathrm{ppm}$ in the dry matter) showed an increase in blood glutathione peroxidase activity, which contributed to the decline in the number of somatic cells in milk. Oltramari et al. (2014) concluded that se reduced Somatic Cells Count and improved mammary gland health.

The decrease in Somatic Cells Count can be explained by the better response of neutrophils to infectious agents that cause mastitis in the cows supplied with organic Se 
Hisham H. Khalifa et al.

(Ibeagha et al., 2009). According to Ortman and Peharson (1999) there is greater Se absorption in the organic form, such as selenomethionine and selenocysteine, compared with inorganic sources, such as sodium selenite and selenate (91 and $81 \%$, respectively).

Selenium reduced Somatic Cells Count and improved mammary gland health and this may be explained by the preventive function of neutrophils and the antioxidant action of Se. According to Sordillo and Aitken (2009) when there is evidence of infection, neutrophils and macrophages migrate from the blood stream to the mammary gland tissue in order to fight infection. The phagocytosis of the infectious agents for the defense cells causes an accentuated increase in the production of cellular oxygen, which is highly toxic. When there are appropriate amounts of Se circulating, these toxic metabolites are neutralised by antioxidant enzymes, mainly GSH-Px, elevating the phagocytic capacity of the organism. On the other hand, Se deficiency results in oxygen accumulation that can cause lesions or even cell lysis.

The Se+Vit E treatment group resulted in low Somatic Cells Count of milk. These findings might be due to an increase in the activity of polymorphonuclear neutrophils (PMN), immune potency and resistance of the animal against infectious diseases. Also, Se is a constructional part of glutathione peroxidase structure and along with vit $\mathrm{E}$ acts as an important biological antioxidant, which prevents the activity of free radicals leading to the udder health and milk quality (Erskine et al., 1990; Erskine et al., 1989).

Table (4): Descriptive statistics (mean \pm S.E.) and test of significance for milk production and constitution parameters of different groups.

\begin{tabular}{|c|c|c|c|c|}
\hline $\begin{array}{l}\text { Treatment } \\
\text { Parameters }\end{array}$ & G1 & G2 & G3 & G4 \\
\hline Milk production & $18.13 \pm 1.08$ & $19.81 \pm 0.54$ & $20.56 \pm 1.06$ & $20.2 \pm 0.45$ \\
\hline Milk fat & $3.67 \pm 0.19$ & $3.5 \pm 0.2$ & $3.7 \pm 0.1$ & $3.71 \pm 0.1$ \\
\hline Milk protein & $2.3 \pm 0.1^{\mathrm{b}}$ & $2.37 \pm 0.08 \mathrm{a}^{\mathrm{b}}$ & $2.6 \pm 0.09^{\mathrm{a}}$ & $2.46 \pm 0.09^{\mathrm{ab}}$ \\
\hline Milk Lactose & $4.42 \pm 0.11$ & $4.45 \pm 0.09$ & $4.66 \pm 0.09$ & $4.53 \pm 0.02$ \\
\hline Milk Total solid & $11.24 \pm 0.42$ & $11.24 \pm 0.26$ & $11.57 \pm 0.14$ & $11.55 \pm 0.19$ \\
\hline Milk Solids not fat & $7.57 \pm 0.25$ & $7.74 \pm 0.11$ & $7.87 \pm 0.12$ & $7.84 \pm 0.1$ \\
\hline Somatic cell count & $312.3 \pm 17.96^{\mathrm{a}}$ & $208.35 \pm 8.13^{\mathrm{ab}}$ & $170.31 \pm 83.01^{\mathrm{ab}}$ & $157 \pm 53.04^{b}$ \\
\hline G1 =control & & G2 = injec & on $10 \mathrm{ml}$ viteselen & \\
\hline
\end{tabular}

Identical letters within each row indicates insignificant difference at $p \leq 0.05$.

\section{Blood parameters}

\section{Glutathione peroxides}

Table (5) showed that treatments had significant effect on glutathione peroxidase where all treatments were significantly higher than control, and G3 and G4 were the highest significantly. The significant effect of treatment with Se or Se+Vit. E was in accordance with the previous results on cows, sheep, lambs or goats by Milad et al. (2001) who reported that GSH-Px activity was significantly higher in the treated group $(\mathrm{P}<0.01 ; \mathrm{P}<0.001$, respectively) than in the control group. Se and vitamin E improved glutathione peroxidase (GSH-Px) activity in blood and increases plasma concentrations of total antioxidant capacity and Se in 
Effect of selenium and vitamin E supplementation as a nutritional treatment for some physiological and productive traits of Holstein dairy cows under Egyptian summer conditions

dairy cattle (Calamari et al., 2011) and goats (Katamoto et al., 1998). Malbe et al. (2002) found that glutathione peroxidase activity increased significantly $(\mathrm{P}<.001)$ for selenium supplemented cows in comparison with activity in non-supplemented cows. Hamam and Hala Abou-Zeina (2007) injection of both vitamin E plus Se, in Baladi ewes, increased significantly the concentrations of natural antioxidants (atocopherol and glutathione peroxidase) in blood of sheep. Faixová et al. (2007) showed that lambs of the second group fed additional Se had greater activity of blood glutathione peroxidase (GPx) $(\mathrm{P}<0.001)$. Results confirmed the positive correlation between blood Se content and the activity of this selenoenzyme. Liu et al. (2008) found that the activity of GSH-Px in blood was significantly increased $(\mathrm{p}<0.05)(\mathrm{p}<0.05)$ when HSe, LSeVE and HSeVE were fed.

Trávníček et al. (2008) the average activity of GSH-Px in the whole blood of ewes of group E1 (1 $147.4 \pm 181.5 \mathrm{U} / \mathrm{g} \mathrm{Hb})$ and E2 (1 $056.1 \pm 267.5 \mathrm{U} / \mathrm{g} \mathrm{Hb})$ was 1.6 and 1.5 times higher, respectively, than in the control group $(697.9 \pm 179.3 \mathrm{U} / \mathrm{g} \mathrm{Hb})(\mathrm{P}<0.001)$. Illek et al., (2009) revealed that the activity of the selenoenzyme glutathione peroxidase is often considered to reflect the selenium concentration in whole blood.

Levels of GSHPx in the SY supplemented groups were significantly higher already in the fourth week of the study (1 wks prepartum) $(\mathrm{P}<0.01)$ and in the SS supplemented group the GSH-Px values were significantly higher than those in the negative control group (NC) only 9 weeks from the start of supplementation. Antunović et al. (2009) carried out trial with lambs fed different dietary supplementation of selenium (inorganic and organic sources) resulting in significantly higher activity of the blood GSH-Px enzyme, compared to the control group without addition of selenium.

Ebrahimi et al. (2011) reported that the glutathione peroxidase activity of calves was significantly greater in the Sel-Plex group $(\mathrm{p}<0.01)$ than that in the control group. Pop et al. (2011) reported that the average activity of glutathione-peroxidase GSH-Px in the experimental group was significantly higher $(6.28 \pm 0.81 \mathrm{~mole} / \mathrm{ml})$ than that measured in comparison with the reference group $(2.48 \pm 0.48$ mole $/ \mathrm{ml})$.

Antunović et al. (2014) showed significant higher GSH-Px activity $(\mathrm{P}<0.01)$ in the lambs blood of experimental groups (Exp.-I and Exp.-II) compared to the control group. Azimi et al. (2015) indicated that there was significant difference among treatments for serum glutathione peroxidase level. The lowest glutathione peroxidase level was related to the control group and the highest level was for calves received vitamin E plus selenium. Administration of vitamin $\mathrm{E}$ and selenium alone increased antioxidant enzyme levels significantly as compared to the control group.

\section{Plasma total proteins, albumen and globulin concentrations}

Table (5) revealed that Se supplementation either with Vit. E or in organic form had no significant effect on plasma total protein, albumin and globulin concentrations although their levels tended to be lower in the control than in all treatments groups except G3 which showed lower level of albumin than control group. This result was in accordance with that of Hamam and Hala Abou-Zeina (2007), Slavik et al.(2008) and Shinde et al. (2009) who found that plasma proteins were not affected by Se supplementation. Also, Arthur et al. (1988), Singh et al. (2002) and Kumar et al. (2009) reported that supplementation of Se had no 
Hisham H. Khalifa et al.

significant effect on serum globulin levels. The insignificantly higher plasma proteins concentrations in Se treated groups than the control group was in accordance with Mudgal et al. (2008) who found that the level of globulin was significantly $(\mathrm{P}<0.01)$ increased in groups supplemented with $0.3 \mathrm{ppm}$ selenium $(\mathrm{Se})$.

\section{Plasma Urea:}

Results illustrated in Table (5) revealed that plasma urea concentration was significantly higher in G4 (organic Se) than in G2 (injection $10 \mathrm{ml}$ viteselen), while no significant differences were found between other groups. The insignificant effect of inorganic Se treatment was in accordance with that of Tahmasbi et al. (2012) who found that treated dairy cows by injection of selenium-vitamin $\mathrm{E}$ had no significant effect on their plasma urea. Meanwhile, Slavik et al. (2008) found that the group of cows received an inorganic Se supplement (sodium selenite) showed an increase in their blood urea level. These contradicting results may be due to protein level in diets as Canfield et al. (1990) concluded that feeding high rumen degradable protein to the cows will result in high blood urea nitrogen concentration.

\section{Plasma Glucose:}

Se supplementation either with Vit. E or in organic form did not affect significantly plasma glucose concentration as shown in Table (5). However, plasma glucose concentration tended to be higher in G4 (organic Se) than in the other three groups. These results were in agreement with that of Calamari et al. (2011) and Tahmasbi et al., (2012) who found that dairy cows treated by sodium selenite or organic Se as well as injection of selenium-vitamin E had no significant effect on their plasma glucose.

\section{Plasma total cholesterol and triglycerides:}

Tables (5) showed that Se supplementation either in inorganic form with Vit. E or in organic form did not affect significantly plasma cholesterol and triglycerides concentrations. However, the highest values of Plasma total cholesterol were recorded by G4 followed by G3, G1 and G2, respectively and that for triglycerides were shown in G3, G1, G2 and G4, respectively. These results are in accordance with that of Tahmasbi et al. (2012) who found that in dairy cows feed of diet contains vitamin $\mathrm{E}$ and/or selenium (Se) supplementation did not affect plasma total cholesterol and triglycerides. Also, the insignificant effect of treatment with Se or Se+Vit. E on triglycerides was in accordance with the previous work on cows, sheep, lambs or goats by Shinde et al. (2009), Soliman et al. (2012), Falkowska et al. (2000), Antunović et al. (2014) and Ziaei, (2015) who reported that selenium supplementation had no significant effect on blood triglycerides.

\section{Plasma ALT and AST}

Table (5) indicated that Se or Se+Vit. E treatment did not affect plasma ALT and AST activities in all groups in summer. The result was in accordance with that of Das et al. (2012) and Antunović et al. (2014) who found that enzyme activity (ALT and AST) in the blood of lambs did not significantly differ depending on the dietary supplementation with selenium. 
Effect of selenium and vitamin E supplementation as a nutritional treatment for some physiological and productive traits of Holstein dairy cows under Egyptian summer conditions

Table (5): Descriptive statistics (mean \pm S.E.) and test of significance for blood plasma and physiological parameters of different groups.

\begin{tabular}{|c|c|c|c|c|}
\hline Parameter & G1 & G2 & G3 & G4 \\
\hline GSH-Px & $4.02 \pm 0.98^{\mathrm{b}}$ & $5.88 \pm 0.53^{\mathrm{ab}}$ & $6.72 \pm 0.16^{\mathrm{a}}$ & $6.57 \pm 0.19^{\mathrm{a}}$ \\
\hline Total protein & $5.72 \pm 0.25$ & $6.03 \pm 0.18$ & $6.06 \pm 0.2$ & $5.9 \pm 0.15$ \\
\hline Albumin & $3.49 \pm 0.24$ & $3.53 \pm 0.05$ & $3.33 \pm 0.22$ & $3.46 \pm 0.12$ \\
\hline Globulin & $2.23 \pm 0.14$ & $2.5 \pm 0.22$ & $2.73 \pm 0.08$ & $2.44 \pm 0.19$ \\
\hline Urea & $20.29 \pm 1.18^{\mathrm{ab}}$ & $18.21 \pm 1.49^{\mathrm{b}}$ & $20.96 \pm 0.8^{\mathrm{a}}$ & $24 \pm 2.53^{\mathrm{a}}$ \\
\hline Glucose & $30.31 \pm 1.48$ & $30.77 \pm 1.34$ & $30.3 \pm 2.03$ & $31.3 \pm 1.12$ \\
\hline cholesterol & $133 \pm 11.82$ & $132.01 \pm 21.07$ & $134.62 \pm 8.51$ & $136.72 \pm 3.04$ \\
\hline Triglyceride & $28.71 \pm 3.06$ & $27.73 \pm 2.23$ & $29.93 \pm 1.32$ & $26.94 \pm 2.02$ \\
\hline ALT & $12.85 \pm 1.78$ & $13.25 \pm 1.3$ & $13.94 \pm 0.79$ & $14.25 \pm 1.4$ \\
\hline AST & $26.75 \pm 1.38$ & $25.05 \pm 2.06$ & $26.31 \pm 1.92$ & $25.15 \pm 1.22$ \\
\hline
\end{tabular}

GSH-Px=Glutathione peroxides

$\mathrm{AST}=$ aspartate aminotransferase

ALT=alanine aminotransferase

$\mathrm{G} 2=$ injection $10 \mathrm{ml}$ viteselen

$\mathrm{G} 1=$ control

G4 =organic selenium

$\mathrm{G} 3$ = injection $20 \mathrm{ml}$ viteselen

Identical letters within each row indicate insignificant difference at $\mathrm{p} \leq 0.05$.

\section{Physiological Parameters}

\section{Rectal temperature}

Tables (6) indicated that Se supplementation either with Vit. E or in organic form did not affect significantly rectal temperature. Similar results had been found by El-Shahat and Abdel-Monem (2011) who showed that there was no significant difference in rectal temperature of experimental animal.

\section{Respiration rate}

Table (6) indicated that Se treatment either as inorganic or organic forms with or without vit. E did not affect respiration rate. This result was similar to that reported by ElShahat and Abdel-Monem (2011) who showed that there was no significant difference in respiratory rates of experimental animal.

Table (5): Descriptive statistics (mean \pm S.E.) and test of significance for rectal temperature and respiration rate of different groups.

\begin{tabular}{|l|c|c|c|c|}
\hline Parameter & G1 & G2 & G3 & G4 \\
\hline Rectal temperature & $38.48 \pm 0.1$ & $38.38 \pm 0.08$ & $38.48 \pm 0.13$ & $38.42 \pm 0.06$ \\
\hline Respiration rate at noon & $53.4 \pm 2.3$ & $51.8 \pm 3.43$ & $50 \pm 2.41$ & $52.6 \pm 3.72$ \\
\hline S.E. = Standard error & G1 $=$ control \\
G2 = injection 10 ml viteselen & G3 = injection $20 \mathrm{ml}$ viteselen \\
G4 =organic selenium & dt = Duncan's Multiple Range Test
\end{tabular}

Conclusions:

Selenium treatment as organic or in-organic forms has no significant role in thermoregulation of dairy cows under summer conditions. It also had no significant effect on kidney or liver functions as well as plasma metabolites. However, it has a significant role against mastitis by decreasing somatic cell count through stimulating the immune system. 


\section{Hisham H. Khalifa et al.}

\section{REFERENCES}

Abd El-Ghany, W.H.; El-Sherbiny, A.A. Khalil, M.H. and Ramadan, W.A. (2010). Role of the wool coat density on some adaptive measurements of Barki sheep under semiarid conditions. Egypt. Basic Applied Physiol., 9 (2): 247-263.

Amundson, J. L.; Mader, T.L.; Rasby, R.J. and Hu, Q.S. (2006). Environmental effects on pregnancy rate in beef cattle. J. Animal Sci., 84(12): 3415-3420.

Antunović, Z.; Novoselec, J.; Klapec, T.; Čavar, S.; Mioč, B. and Šperanda, M. (2009). Influence of different selenium sources on performance, blood and meat selenium content of fattening lambs. Italian J. Animal Sci., 8(3): 163-165.

Antunović, Z.; Novoselec, J.; Šperanda, M.; Klapec, T.; Ćavar, S.; Mioč, B. and Vuković, R. (2014). Influence of dietary supplementation with selenium on blood metabolic profile and thyroid hormones activities in fattening lambs. Pakistan Veterinary J., 34(2): 224-228.

Arthur, J.R.; Morrice, P.C. and Beckett, G.J. (1988). Thyroid hormone concentrations in selenium deficient and selenium sufficient cattle. Res. in veterinary Sci.,45(1): 122123.

Azimi, i.; Sadeghi, A.A. and Shawrang, P. (2015). The effects of administration of selenium and vitamin e on blood cell count and plasma antioxidant capacity in holstein calves under stress. IJBPAS, 4(5):2810-2819.

Balicka-Ramisz, A. and Jastrzębski, G. (2014). Effect of selenium on the development of selected indicators of fertility in dairy cows. Veterinary World, 7(10): 863-867.

Brigelius-Flohe, R. and Traber, M.G. (1999). Vitamin E: function and metabolism. The FASEB Journal, 13(10): 1145-1155.

Calamari, L.; Petrera, F.; Abeni, F. and Bertin, G. (2011). Metabolic and hematological profiles in heat stressed lactating dairy cows fed diets supplemented with different selenium sources and doses. Livestock Sci., 142(1): 128-137.

Canfield, R.W.; Sniffen, C. J. and Butler, W.R. (1990). Effects of excess degradable protein on postpartum reproduction and energy balance in dairy cattle. J. Dairy Sci., 73(9): 2342-2349.

Das, T. K.; Mani, V.; Kaur, H.; Kewalramani, N. and Agarwal, A. (2012). Effect of vitamin E supplementation on hematological and plasma biochemical parameters during long term exposure of arsenic in goats. Asian Australasian J. Anim. Sci., 25(9): 12621268.

Duncan, D. B. (1955). Multiple range and multiple F tests. Biometrics, 11(1): 1-42.

Duncan, S. E.; Christen, G.L. and Penfield, M.P. (1991). Rancid flavor of milk: relationship of acid degree value, free fatty acids, and sensory perception. J. Food Sci., 56(2): 394-397.

Ebrahimi, M.; Towhidi, A.; Ganjkhanlou, M. and Amini, M. (2011). The effects of organic selenium (Sel-Plex) on the viability of pneumonic Holstein suckling calves. Iranian J. Veterinary Med., 5(3): 163-168.

El-Nenaey, M.H.A. (1993). Effect of some feed supplementation on productive and reproductive performance of farm animals. Ph.D. Thesis, Animal Production Department, Faculty of Agriculture, Shebin El- Korn, Minufiya University, Egypt. 
Effect of selenium and vitamin E supplementation as a nutritional treatment for some physiological and productive traits of Holstein dairy cows under Egyptian summer conditions

El-Shahat, K.H. and Abdel Monem, U.M. (2011). Effects of dietary supplementation with vitamin $\mathrm{E}$ and/or selenium on metabolic and reproductive performance of Egyptian Baladi ewes under subtropical conditions. World Applied Sci. J., 12: 1492-1499.

Erskine, R.J.; Eberhart, R.J. and Scholz, R.W. (1990). Experimentally induced Staphylococcus aureus mastitis in selenium-deficient and selenium-supplemented dairy cows. American J. Veterinary Res., 51(7):1107-1111.

Erskine, R. J.; Eberhart, R. J.; Grasso, P. J. and Scholz, R.W. (1989). Induction of Escherichia coli mastitis in cows fed selenium-deficient or selenium-supplemented diets. American J. Veterinary Res., 50(12): 2093-2100.

Eulogio, G.L.J.; Hugo, C.V.; Antonio, C.N.; Alejandro, C.I. and Juan, M.Q. (2012). Effects of the selenium and vitamin $\mathrm{E}$ in the production, physicochemical composition and somatic cell count in milk of Ayrshire cows. J. Animal. Veterinary. Adv., 11: 687691.

Faixova, Z.; Faix, Š.; Leng, L.; Vaczi, P.; Makova, Z. and Szaboova, R. (2007). Haematological, blood and rumen chemistry changes in lambs following supplementation with Se-yeast. Acta Veterinaria Brno, 76(1): 3-8.

Falkowska, A. and Minakowski, D. (2000). The effect of supplementing rations with selenium and vitamin $\mathrm{E}$ on biochemical parameters in blood and performance of cows in the early stage of lactation. J. Animal and Feed Sci., 9(2): 271-282.

Faye, B.; Saleh, S.K.; Konuspayeva, G.; Musaad, A.; Bengoumi, M. and Seboussi, R. (2014). Comparative effect of organic and inorganic selenium supplementation on selenium status in camel. J. King Saud Univ. Science, 26(2):, 149-158.

Hamam, A.M. and Abou-Zeina, H.A. (2007). Effect of vitamin E and selenium supplements on the antioxidant markers and immune status in sheep. J. Biol. Sci., 7: 870-878.

Harrison, G.A.; Tricarico, J.M. and Elliott, S.A. (2005). Effect of Sel-Plex (TM) supplementation on milk production, composition and somatic cell count of lactating dairy cows in commercial dairy herds. J. Dairy Sci., 88 (1): 60.

Heard, J.W.; Stockdale, C.R.; Walker, G.P.; Leddin, C.M.; Dunshea, F.R.; McIntosh, G.H. and Doyle, P.T. (2007). Increasing selenium concentration in milk: effects of amount of selenium from yeast and cereal grain supplements. J. Dairy Sci., 90(9): 4117-4127.

Ibeagha, A.E.; Ibeagha-Awemu, E.M.; Mehrzad, J.; Baurhoo, B.; Kgwatalala, P. and Zhao, $X$. (2009). The effect of selenium sources and supplementation on neutrophil functions in dairy cows. Animal, 3(7): 1037-1043.

Illek, J.; Kumprechtova, D. and Ballet, N. (2009). Effects of dietary selenium source and level on selenium contents in blood, colostrum and milk and metabolic profile in dairy cows. In $18^{\text {th }}$ International Science Symposium on Nutrition of Domestic Animals.

Johnson, H.D. ; M.D. Shanklin and L. Hahn (1989). Productive adaptability indices of Holstein cattle to environmental heat. Agric. Forest Meteorol. Conf., pp. 291 - 297.

Juniper, D.T.; Phipps, R.H.; Jones, A.K. and Bertin, G. (2006). Selenium supplementation of lactating dairy cows: effect on selenium concentration in blood, milk, urine, and feces. J. Dairy Sci., 89(9): 3544-3551. 
Hisham H. Khalifa et al.

Katamoto, H.; Fukuda, H.; Oshima, I.; Ishikawa, N. and Kanai, Y. (1998). Nitroblut Tetrazolium Reduction of Neutrophils in Heat Stressed Goats Is Not Influenced by Selenium and Vitamin E Injection. J. Veterinary Med. Sci., 60(11): 1243-1249.

Koyuncu, M. and Yerlikaya, H. (2007). Short Communication effect of selenium-vitamin E injections of ewes on reproduction and growth of their lambs. South Afr. J. Animal Sci., 37(4): 233-236.

Krzyżewski, J.; Bagnicka, J.O.H. and Horbańczuk, J.O. (2014). The effect of selenium supplementation to the diet of dairy cows and goats on production traits and animal health. A review. Animal Science Papers and Reports, 32(4): 283-299.

Kumar, R. and Puri, J.P. (2009). Influence of environmental variations on blood metabolites in buffaloes. Pakistan J. Zoology. Suppl. Ser., 9: 289-291.

Liu, Z.L.; Yang, D.P.; Chen, P.; Dong, W.X. and Wang, D.M. (2008). Supplementation with selenium and vitamin $\mathrm{E}$ improves milk fat depression and fatty acid composition in dairy cows fed fat diet. Asian Australasian J. animal Sci., 21(6): 838-844.

Malbe, M.; Klaassen, E.; Kaartinen, L.; Attila, M. and Atroshi, F. (2002). Effects of oral selenium supplementation on mastitis markers and pathogens in Estonian cows. Veterinary therapeutics: research in applied veterinary medicine, 4(2): 145-154.

Marai, I.F.M. and A.A.M. Habeeb (2010). Buffalo's biological functions as affected by heat stress-a review. Livestock Science., 127: 89-109.

McDowell, L.R.; Williams, S.N.; Hidiroglou, N.; Njeru, C.A.; Hill, G.M.; Ochoa, L. and Wilkinson, N. S. (1996). Vitamin E supplementation for the ruminant. Animal Feed Sci. Technol., 60(3): 273-296.

Meschy, F. (2000). Recent progress in the assessment of mineral requirements of goats. Livestock Production Science, 64(1): 9-14.

Mihaliková, K.; Boldižárová, K.; Faix, Š. and Kišidayová, S. (2005). The effects of organic selenium supplementation on the rumen ciliate population in sheep. Folia Microbiologica, 50(4): 353-356.

Milad, K.; Kovac, G.; Racz, O.; Sipulova, A. and Bajova, V. (2001). Effect of vitamin E and selenium on blood glutathione peroxidase activity and some immunological parameters in sheep. Veterinarni Medicinapraha, 46(1): 1-5.

Moeini, M.M.; Kiani, A.; Mikaeili, E. and Shabankareh, H.K. (2011). Effect of prepartum supplementation of selenium and vitamin $\mathrm{E}$ on serum $\mathrm{Se}$, IgG concentrations and colostrum of heifers and on hematology, passive immunity and Se status of their offspring. Biological Trace Element Res., 144(1-3): 529-537.

Morgante, M.; Beghelli, D.; Pauselli, M.; Dall'Ara, P.; Capuccella, M. and Ranucci, S. (1999). Effect of administration of vitamin $\mathrm{E}$ and selenium during the dry period on mammary health and milk cell counts in dairy ewes. J. Dairy Sci., 82(3): 623-631.

Mudgal, V.; Garg, A.K.; Dass, R.S. and Varshney, V.P. (2008). Effect of selenium and copper supplementation on blood metabolic profile in male buffalo (Bubalus bubalis) calves. Biological Trace Element Res., 121(1): 31-38.

Nockels, C.F. (1986). Nutrient modulation of the immune system. Recent Advances in Animal Nutr., 177.

NRC (2001). Nutrient Requirements of Dairy Cattle. $7^{\text {th }}$ rev. ed. Natl. Acad. Sci., Washington, DC. 
Effect of selenium and vitamin E supplementation as a nutritional treatment for some physiological and productive traits of Holstein dairy cows under Egyptian summer conditions

Oliver, S.P. and Calvinho, L.F. (1995). Influence of inflammation on mammary gland metabolism and milk composition. J. Animal Sci., 73(2): 18-33.

Oltramari, C. E.; Pinheiro, M.D.G.; De Miranda, M.S.; Arcaro, J. R.; Castelani, L.; Toledo, L.M. and Júnior, I.A. (2014). Selenium sources in the diet of dairy cows and their effects on milk production and quality, on udder health and on physiological indicators of heat stress. Italian J. Animal Sci.,13(1): 2921.

Ortman, K. and Pehrson, B. (1999). Effect of selenate as a feed supplement to dairy cows in comparison to selenite and selenium yeast. J. Animal Sci., 77(12): 3365- 3370.

Paschoal, J.J.; Zanetti, M.A.; Del Claro, G.R.; Melo, M.P.D.; Pugine, S.P. and Cunha, J.A. (2007). Fatty acid profile and oxidative stability of milk from Holstein cows fed with extruded soybean and organic selenium. Pesquisa Agropecuária Brasileira, 42(12): 1793-1799.

Pechova, A.; Misurova, L.; Pavlata, L. and Dvorak, R. (2008). Monitoring of changes in selenium concentration in goat milk during short-term supplementation of various forms of selenium. Biological Trace Element Res., 12(2): 180-191.

Pirestani, A.; Bagheri, M.J.; Hashemi, S.M. and Asgarishahi, A.H. (2014). The effect of selenium, vitamin e and copper injection on the somatic cell count and milk compositions in dairy cows. J. Farm Animal Nutr. Physiol., 9(1): 41-49.

Politis, I.; Hidiroglou, M.; Batra, T.R.; Gilmore, J.A.; Gorewit, R.C. and Scherf, H. (1995). Effects of vitamin E on immune function of dairy cows. Amer. J. Veter. Res., 56(2): 179-184.

Politis, I.; Hidiroglou, N.; White, J.H.; Gilmore, J.A.; Williams, S.N.; Scherf, H. and Frigg, M. (1996). Effects of vitamin E on mammary and blood leukocyte function, with emphasis on chemotaxis, in periparturient dairy cows. Amer. J. Veter. Res., 57(4): 468-471.

Pop, I. M.; Radu-Rusu, C.; Simeanu, D.; Pop, C.; and Fleancu, N. (2011). Effects induced by a source of organic selenium and E vitamin usage in dairy cattle feeding. Lucrari Stiinfifice - Seria Zootehnie, 55(16): 160-164.

Qureshi, Z.I.; Siddiq, M.; Lodhi, L.A.; Muhammad, G. and Jamil, H. (2010). Effect of vitamin E-selenium administration during late gestation on productive and reproductive performance in dairy buffaloes and on growth performance of their calves. Pakistan Veter. J., 30(2): 83-86.

Ružić-Muslić, D.; Petrović, M.P.; Caro-Petrović, V.; Petrović, M.M.; Bijelić, Z.; Ilic, Z. and Stojković, J. (2014). Effects of adding different forms of selenium in diets for fattening lambs. Biotechnology in Animal Husbandry, 30(4): 589-600.

Sánchez, J.; Montes, P.; Jimenez, A.and Andres, S. (2007). Prevention of clinical mastitis with barium selenate in dairy goats from a selenium-deficient area. J. Dairy Sci., 90(5):2350-2354.

Shinde, P.L.; Dass, R.S. and Garg, A.K. (2009). Effect of vitamin E and selenium supplementation on haematology, blood chemistry and thyroid hormones in male buffalo (Bubalus bubalis) calves. J. Animal and Feed Sci., 18(2): 241-256. 


\section{Hisham H. Khalifa et al.}

Silanikove, N.; Maltz, E.; Halevi, A. and Shinder, D. (1997) Metabolism of water, sodium, potassium and chloride by high yielding dairy cows at the onset of lactation. J. Dairy Sci., 80: 949-956.

Silvestre, F.T.; Rutigliano, H.M.; Thatcher, W.W.; Santos, J.E. and Staples, C.R. (2007). Effect of selenium source on production, reproduction, and immunity of lactating dairy cows. In : Florida Ruminant Nutrition Symposium. Gainesville, FL.

Singh, R.; Randhawa, S.S. and Dhillon, K.S. (2002). Changes in blood biochemical and enzyme profile in experimental chronic selenosis in buffalo calves (Bubalus bubalis). Indian J. Animal Sci., 72(3): 230-232.

Slavik, P.; Illek, J.; Brix, M.; Hlavicova, J.; Rajmon, R. and Jilek, F. (2008). Influence of organic versus inorganic dietary selenium supplementation on the concentration of selenium in colostrum, milk and blood of beef cows. Acta Veterinaria Scandinavica, 50(1): 1-6.

Soliman, E.B.; El-Moty, A.K.I. and Kassab, A.Y. (2012). Combined effect of vitamin E and selenium on some productive and physiological characteristics of ewes and their lambs during suckling period. Egypt. J. Sheep and Goat Sci., 7(2): 31-42.

Sordillo, L.M. and Aitken, S.L. (2009). Impact of oxidative stress on the health and immune function of dairy cattle. Veterinary Immunology and Immunopathology, 128(1): 104-109.

SPSS. (1997). SPSS for Windows. Statistical Package for the Social Sciences. Release 8.0.

Tahmasbi, A.M.; Kazemi, M.; Moheghi, M.M.; Bayat, J. and Shahri, A.M. (2012). Effects of selenium and vitamin $\mathrm{E}$ and night or day feeding on performance of Holstein dairy cows during hot weather. J. Cell and Animal Biol., 6(3): 33-40.

Trávníček, J.; Racek, J.; Trefil, L.; Rodinová, H.; Kroupová, V.; Illek, J. and Písek, L. (2008). Activity of glutathione peroxidase (GSH-Px) in the blood of ewes and their lambs receiving the selenium-enriched unicellular alga Chlorella. Czech J. Animal Sci., 53(7): 292-298.

Wang, C.; Liu, Q.; Yang, W.Z., Dong, Q.; Yang, X.M.; He, D.C. and Huang, Y.X. (2009). Effects of selenium yeast on rumen fermentation, lactation performance and feed digestibilities in lactating dairy cows. Livestock Science, 126(1): 239-244.

Weiss, W. (2002). Relationship of mineral and vitamin supplementation with mastitis and milk quality. Processing Annual Meeting National Mastitis Council, Orlando, Florida, USA, pp: 37-44.

Ziaei, N. (2015). Effect of selenium and vitamin E supplementation on reproductive indices and biochemical metabolites in Raieni goats. J. Appl. Animal Res., 43 (4), 426-430.

Zong-yun, X. U., Li-juan, Z., and Jun-wen, H. (2007). Effects of Se-Yeast in Dairy Ration on Somatic Cell and Antioxidation Performance. Chinese J. Animal Nutr., 19: (6) 1-5. 
Effect of selenium and vitamin $E$ supplementation as a nutritional treatment for some physiological and productive traits of Holstein dairy cows under Egyptian summer conditions
تأثير اضافة السيلينيوم وفيتامين E كمعلات غذائية على بعض الصفات الفسيولوجية والانتاجية لابقار الهولشتين الحلابة تحت ظروف فصل الصيف في مصر الصفات الصن

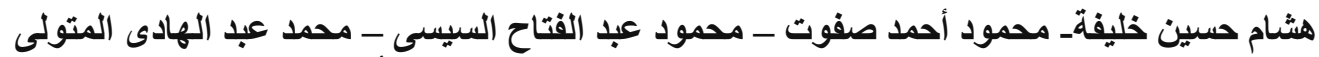

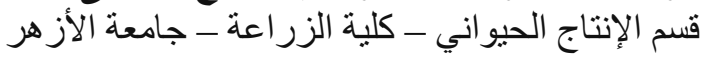

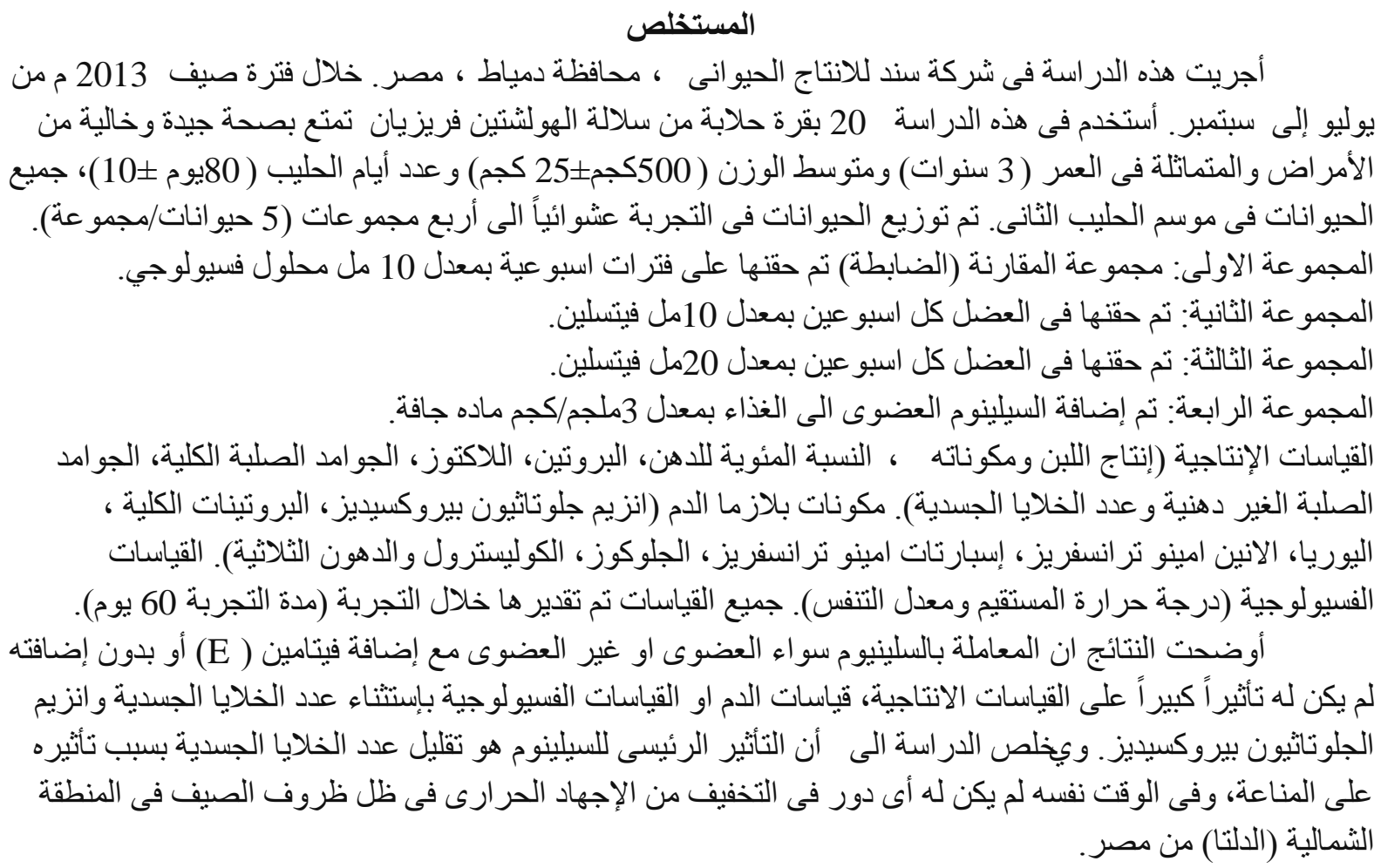

